\title{
頸椎前方除圧固定術（プレート不使用）の骨癒合
}

\author{
総合せき損センター整形外科 \\ 山本 俊 策・植 田 尊 善

\section{Fusion Rates of Anterior Cervical Discectomy and Interbody Fusion without Plate Instrumentation}

\author{
Shunsaku Yamamoto, and Takayoshi Ueta \\ Department of Orthopaedic Surgery, Spinal Cord lnjuries Center, \\ Fukuoka, Japan
}

\begin{abstract}
We retrospectively reviewed 76 patients who had undergone anterior cervical discectomy and interbody fusion without plate instrumentation. They consisted of 62 males and 14 females and were follwed up for an average of 23.1 months (3-48 months). Dynamic roentgenograms taken after surgery were reviewed and final decision was made based on flexion-extension roentgenograms and disappearance of clear zone between a vertebra and bone graft. The overall union rate was $92 \%$ (70 of 76patients) and mean time to union was 5.8 months. Solid arthrodesis was achieved in $94 \%$ of patients with one-level fusion (48 of 51patients) , 88\% of those with two-level fusion (21 of 24 patients), and 100\% of those with three-level fusion (1 of 1patient). Pseudoarthrosis with motion was noted in 6 patients. Anterior cervical discectomy and interbody fusion without plate instrumentation results in acceptable fusion rates for not only single-level but also multi-level fusion.
\end{abstract}

Key words : anterior cervical discectomy and interbody fusion (頸椎前方除圧固定術), without plate instrumentation（プレートなし）, fusion rate（骨癒合率）

目 的

当院において国分法に準じ，プレートを使用せず腸 骨からの半層骨を移植骨とする, 頸椎前方除圧固定術 の骨癒合を検討したので報告する。

\section{対 象}

調查対象は 1999 年から 2000 年の 2 年間に国分法に 準じた頸椎前方除圧固定術を行い, 経過観察可能であっ た 76 例（男性 62 例 女性 14 例）手術時平均年齢 52.8 歳（25 歳-79 歳）経過観察期間平均 23.1 ヶ月（3 ヶ月-48 ヶ月）であった。診断の内訳は, 頸椎症性脊 䯣症 30 例, 頸椎椎間板へルニア 24 例, 頸椎症性筋萎 縮症 11 例, 頸椎症性神経根症 9 例, 後縦勒带骨化症
2 例であった。

$$
\text { 方法 }
$$

評価方法は, 単純レントゲン側面像での移植骨と母 床の界面間 Clear zone の有無と側面機能撮影での棘 突起間隔の動きの有無で判定した.

\section{結果}

骨癒合は 76 例中 70 例にて認められた。全体の癒合 率は $92 \%$, 骨癒合平均期間は 5.8 ヶ 月（3 ヶ月 -36 ヶ 月）であった。 1 椎間では $94 \%$ (51 例中 48 例)，2 椎 間では $88 \%$ (24 例中 21 例)，3 椎間では 1 例である が 100\%の癒合率であった．残りの 6 例はいずれも下 位の母床と移植骨の骨癒合は認められているが, 上位 


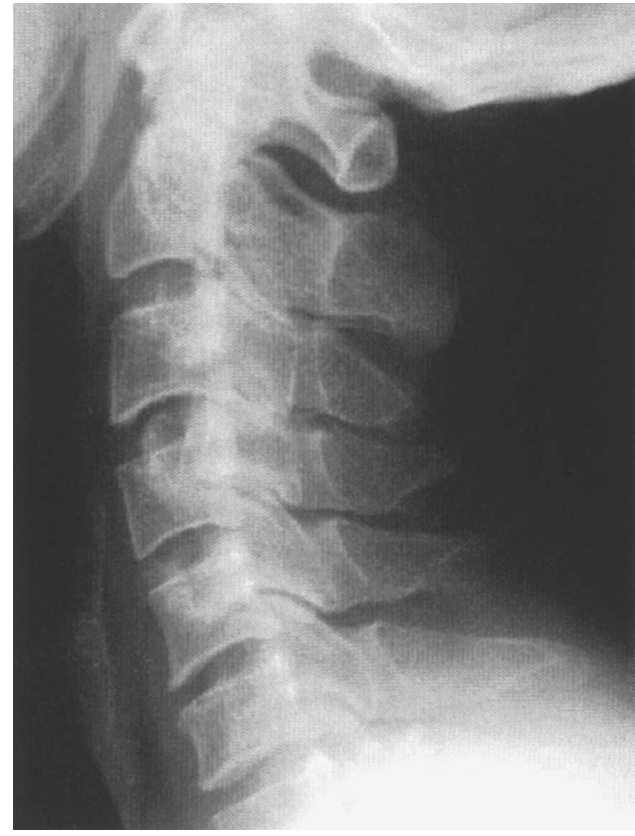

図A

43 歳男性, 頸椎椎間板ヘルニアと診断

した. (図 A)
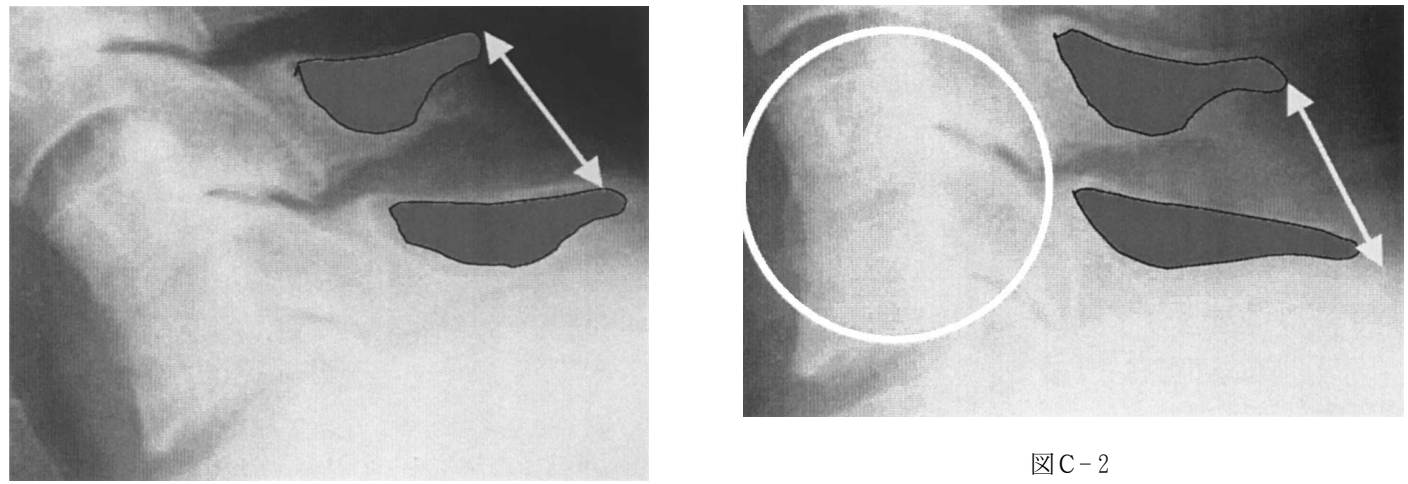

図 $\mathrm{C}-2$

図C-1

C5/6 ASF 施行. 術後 3 ヶ月の側面機能撮影 (図 B) にて移植骨と母床の界面間 clear zone の 消失之屈曲 (図 $\mathrm{C}-1$ ), 伸展時 (図 $\mathrm{C}-2$ ), 棘突起間の動きの消失を認めた. 
の母床と移植骨との癒合の遷延が認められているため, 現在経過観察中である.

\section{症例}

43 歳男性, 頸椎椎間板ヘルニアと診断した。（図 A)

C5/6ASF 施行し, 術後 3 ヶ月の側面機能撮影（図 B）にて移植骨と母床の界面間 clear 消失と棘突起間 の動きの消失を認めた。（図 C1 C2）

\section{考察}

近年，単椎間においてもプレートを使用した頸椎前 方除圧固定術の頻度が増加しているが，多椎間にわた る頸椎前方除圧固定術においてもプレートを使用せず, 良好な骨癒合を獲得することができた。また，今回調 査した症例内では移植骨の明らかな脱転は認められな かったが，程度の差はあるものの，ほぼ全例に移植骨 の母床への陥入を認めた. その結果, 局所的な頸椎後 弯变形を呈したが, 術前と比較して明らかな症状の増 悪を認めなかった。 文献上, 骨移植後の固定椎体高 (vertebral height) は術後 3 ヶ月迄は平均 8.45\%減 少するが，その後骨癒合し一定化する傾向がみられた としている ${ }^{1,2,3)}$.

術後経過観察期間中の側面機能撮影での棘突起の動 きは簡便で感度が高い評価方法であり，1 $\mathrm{mm}$ を越 える間隔の变化は偽関節と考えた。 通常, 頸椎カラー による外固定期間を 3 ヶ月とし，多くはその期間での 骨癒合を獲得できたが，6ヶ月を越えて骨癒合を認め る症例を 11 例認めた。 また， 1 例ではあるが 3 年の 経過で癒合を認めた症例ああり, 偽関節の判定には 2 年程度の期間が必要と考える.

一方，プレートを用いた頸椎前方除圧固定術におい
ては，文献上，術後経過観察期間中で頸椎の良好なア ライメントを獲得し, 頸椎局所の後弯变形予防が可能 である。また, 骨癒合はほぼ 100\%に認められ, mortality や神経損傷はなかったとしながらも，プレート 固定に起因する合併症として，スクリューのゆるみが 最む多く約 $5 \%$ であったとの報告む認められた ${ }^{4,5,6,7)}$.

\section{結語}

国分法に準じた頸椎前方除圧固定術においてプレー 卜を使用せず，良好な骨癒合を獲得することができた。

\section{参 考 文 献}

1) Cauthen, JC, et al. : outcome analysis of noninstrumented anterior cervical discectomy and interbody fusion in 348 patients. Spine, 23(2) : 188-92, 1998.

2) Epstein NE. : Anterior cervical diskectomy and fusion without plate instrumentation in 178 patients. J. Spinal Disord, 13(1) : 1-8, 2000.

3) Gore, DR. : The arthrodesis rate in multilevel anterior cervical fusions using autogenous fibula. Spine, 26(11) : 1259-63, 2001.

4）落合信靖他：経験と考察 頸椎前方固定術における頸 椎プレートの有用性. 整形外科 (0030-5901) 54(2)：131135, 2003.

5）谷口 睦他：頸椎前方固定術における頸椎プレート適 応と限界. 中部日本整形外科災害外科学会雑誌 (00089443) 38(4)：863-864, 1995.

6）富永悌二，甲州啓二，吉本高志：Screw-plate による頸 椎前方固定術 Caspar plate と Synthes plate の使用経 験. 脳神経外科ジャーナル (0917-950X) 4(5)：449-457, 1995.

7）冨永悌二他：【頸椎前方固定術における人工材料使用 の長期予後】頸椎前方プレート長期成績. 脊椎脊䯣ジャー ナル (0914-4412) 13(1) : 51-54, 2000. 